\title{
Analysis of Training Factors Against Employee Performance of one of the largest car financed companies in Medan, Indonesia
}

\author{
Irwanto $^{1}$, Iswandi Idris ${ }^{2 *}$, Yeni Rachmawati ${ }^{3}$, Siska Hasibuan $^{4}$, Surti Zahra ${ }^{5}$ \\ \{irwanirone2@ gmail.com ${ }^{1}$, iswandi.idris@plm.ac.id ${ }^{2 *}$, yeni.rachmawati44@ gmail.com ${ }^{3}$, \\ siska.hasibuan@yahoo.com ${ }^{4}$, zahra3803@gmail.com ${ }^{5}$ \} \\ Administration Business, Politeknik LP3I Medan, Medan, Indonesia ${ }^{1,3,4}$ \\ Industrial Engineering, Politeknik LP3I Medan, Medan, Indonesia ${ }^{2 *}$ \\ Management, Universitas Bina Bangsa, Serang, Banten, Indonesia ${ }^{5}$
}

\begin{abstract}
Providing training is very important in an organization because training does not only utilize labor, but also an effort to advance employees in carrying out their respective duties. There are other important factors that affect the performance; namely job training, training is an effort to improve the quality of human resources at work. The purpose of this study is: 1) to find out and analyze the training factors on the performance of employees of car financed companies in Medan, 2) to find out the factors that most influence work performance in the Accounts Receivable section of car financed companies in Medan. Data collection is done by questionnaire. Data collection is done by questionnaire. Data analysis techniques using simple linear regression with reliability test analysis, multiple regression test, multiple correlation test, F test, and t test, and hypothesis testing with the help of SPSS
\end{abstract}

Keywords: Training Factors, Employee Performance, car financed companies

\section{Introduction}

The transformational leadership style can encourage and motivate employees to increase the extra role and performance of employees [1]. Job satisfaction is related to the task environment, while motivation is related to achievement in organizational empowerment [1]. Management of human resource management must, of course, be carried out by professional leaders, in order to support the quality of employees, one of them is held job training for employees. the participants' level of satisfaction with their experiences of the career opportunities, work-life balance, training and development opportunities and characteristics of the jobs offered by the company [2], the relationship between achievement striving and turnover intention in the hospitality industry [3], training programs, consulting services [4], and influences employee performance and well-being [5], that mediates the relation- ship between customer satisfaction and organizational performance [6], transformational leadership and organizational commitment to employee performance [7]. Improve service and customer satisfaction, coordinate every part in the company and improve the quality of management policies [8]. This training is very important to be held in the company because increased productivity and work performance [9]. It is designed for employees to fix their performance weaknesses, obtain specific attitudes, abilities, expertise, knowledge, experiences, and behaviors related to work. The knowledge that is owned directly by employees can carry out activities or certain jobs, which will later have an impact on work productivity achieved by employees. High-intensity interval training (HIIT) is promoted as a time-efficient strategy to 
improve body composition [10], Management plays an important role in improving thework productivity of employees by providing various forms of job training, job sharing and appropriate job placement and create conditions and a safe and comfortable working environment [11].

The existence of a training program can be known by evaluating employee performance by looking at the level of employee performance. Skills Training Strategies [12]. The new training program will significantly increase participants' individual innovative work behavior [13], service standards and training may not be sufficient to guarantee quality employee performance [14]. Participants, trainer, training material and the organization had a positive relationship with the effectiveness of training [15]. According to Mangkunegara [16], in connection with the implementation of the task of developing the training program it is necessary to pay attention to the training methods below:

1. On the job

2. Vestibule

3. Method Demonstrasi

4. Simulate

5. Apprenticeship

6. Classroom Method

Work performance is the result of work in quality and quantity achieved by an employee in carrying out his duties in accordance with the responsibilities given to him [16].

The factors that influence work performance are ability factors and motivational factors

1) Ability Factor

2) Motivation Factor

The aspects of work performance [17] are as follows:

1) Work Results

2) Job Knowledge

3) Initiative

4) Mental dexterity

5) Attitude

6) Discipline of time and attendance

Appraisers after knowing the definition, purpose, and elements to be assessed, also must know the value scale and valuation methods used in employee performance appraisals in the company or organization [18]. Attitudes and behaviors of the contact employees can influence customers [19]

The employee performance evaluation method is basically grouped into two, namely:

1. Traditional methods
a. Rating scale
b. Employee compilation
c. Checklist
d. Freeform Essay
e. Critical incident

2. Modern Methods
a) Assessment centre
b) Management by objective
c) Human asset accounting 


\section{Research Methods}

The author conducts research on one of the largest car financed companies in Medan. The data sources used in this study are primary and secondary data. Data obtained by the author directly from the largest car financed companies in Medan. The method used is filling out the questionnaire. The data sources used by the author are internal and external data. In this study obtained direct data from the largest car financed companies in Medan. As for the population in this study are all employees of the largest car financed companies in Medan, amounting to 29 people. In this study using a saturated sampling technique or all populations were sampled because the population was below 100 people. Based on the pre-research conducted 29 respondents were obtained. The researcher gives a weight value using a Likert scale. In this study Test Validity, Reliability, Multiple Regression Analysis, Double Correlation Analysis (R), Determination, F Test [20] and t Test [21] will be carried out using the SPSS V.22 auxiliary application program.

Table 1. Variable Operational Definition

\begin{tabular}{|c|c|c|c|}
\hline Variable & Definition & Indicator & Scale \\
\hline $\begin{array}{l}\text { Employee } \\
\text { training (X) }\end{array}$ & $\begin{array}{l}\text { Training is a process to shape } \\
\text { and equip employees by adding } \\
\text { their skills, abilities, knowledge, } \\
\text { and behavior [22] }\end{array}$ & $\begin{array}{l}\text { 1. Participants in Training } \\
\text { 2. Instructors / Trainers } \\
\text { 3. Training Materials } \\
\text { 4. Training Location } \\
\text { 5. Training Environment } \\
\text { 6. Training Time }\end{array}$ & Likert Scale \\
\hline $\begin{array}{l}\text { Achievement } \\
\text { employee work } \\
\text { (Y) }\end{array}$ & $\begin{array}{l}\text { "Work Achievement is the work } \\
\text { of quality and quantity achieved } \\
\text { by an employee in carrying out } \\
\text { his duties in accordance with } \\
\text { the responsibility given to him } \\
\text { [16]. }\end{array}$ & $\begin{array}{l}\text { 1) Ability Factor } \\
\text { 2) Motivation Factor }\end{array}$ & Likert Scale \\
\hline
\end{tabular}

\section{Research Results And Discussion}

This Companies is one of the largest car and heavy equipment finance companies in Indonesia, began operations in 1983. The author conducted a quantitative study by giving questionnaires to employees of the largest car financed companies in Medan, amounting to 29 people. The questionnaire made consisted of 2 variables including the independent variable namely employee training and the dependent variable namely work performance. In the independent variable, there are 6 indicators including training participants, trainers, training materials, training locations, training environments, training times. Whereas the dependent variable consists of 2 indicators including the Ability Factor, and the Motivation Factor.

Table 2. Data Percentage Table Based on Indicators

\begin{tabular}{llll}
\hline No & Variable $(\mathrm{X})$ & Score & Persentage \\
\hline 1 & Participants & 247 & $16,43 \%$ \\
2 & Trainer & 252 & $16,76 \%$ \\
3 & Material & 250 & $16,63 \%$ \\
4 & Environment & 254 & $16,89 \%$ \\
5 & Location & 251 & $16,70 \%$ \\
6 & Time & 249 & $16,56 \%$ \\
Total & 1503 & 100 \\
\hline
\end{tabular}


From the results of the above research it can be concluded that the most influential factors give added value to the causes of training. The work performance of these employees is the environment variable percentage of $16.89 \%$, while for the next sequence the trainer variable is $16.76 \%$, location variable is $16,70 \%$, the next sequence of material variables is $16.63 \%$, the time variable is $16.56 \%$, and the participant variable is $16.43 \%$. These results can be seen in the following Figure 1.

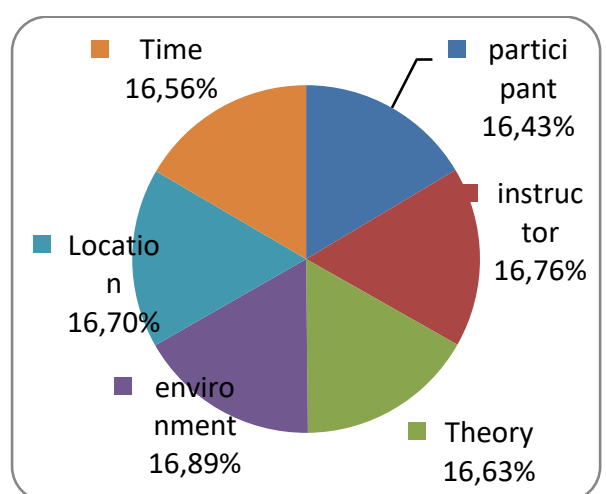

Fig.1. Percentage of Training Variable Diagram

\section{Reliability Test Analysis Results}

To find out the results of the reliability test, using a computer software application program tool, namely SPSS version 22.0, the Cronbach Alpha results were 0.488 as shown in table 4.26 below:

Table 3. Results Cronbach Alpha

\begin{tabular}{|r|r|}
\hline Cronbach's Alpha & N of Items \\
\hline 0,488 & 13 \\
\hline
\end{tabular}

\section{Analysis Test Multiple Regression}

Linear Regression is used to test the relationship between the dependent variable (dependent) with one or several independent variables (free) displayed in the form of a regression equation. If the dependent variable is associated with only one independent variable, the resulting regression equation is simple linear regression (Linear regression). ) If the independent variable is more than one, the regression equation is multiple linear regression.

Table 4. Double Correlation Analysis (R)

\begin{tabular}{|l|r|r|r|r|}
\hline Model & R & R Square & Adjusted R Square & Std. Error of the Estimate \\
\hline 1 &, $838^{\mathrm{a}}$ &, 702 &, 479 &, 19760 \\
\hline
\end{tabular}

\section{Double Correlation Results Table}

Based on the table above, the $\mathrm{R}$ number is 0.838 . This shows that there is a very strong relationship between the independent variable and the dependent variable. 


\section{Analysis Determination $\left(\mathbf{R}^{2}\right)$}

Table 5. Result Analysis Determination

\begin{tabular}{|l|l|l|l|l|}
\hline Model & R & R Square & Adjusted R Square & Std. Error of the Estimate \\
\hline 1 &, $838^{\mathrm{a}}$ &, 702 &, 479 &, 19760 \\
\hline
\end{tabular}

Based on the table above, the number R2 (R Square) is 0.702 or $70 \%$. This shows that the contribution percentage of the effect of the independent variable on the dependent variable is $70 \%$. While the rest $(100-70 \%=30 \%)$ is influenced or explained by other variables not included.

\section{Joint Regression Coefficient Test (Test F)} table below:

From the results of the regression analysis, we can find the $\mathrm{F}$ value as shown in the

Table 6. F Test Results

\begin{tabular}{lllllll}
\hline Model & Sum of Squares & Df & Mean Square & F & Sig. \\
\hline 1 & Regression & 1,472 & 12 &, 123 & 3,142 &, $017^{\mathrm{b}}$ \\
& Residual &, 625 & 16 &, 039 & & \\
\cline { 3 - 5 } & Total & 2,097 & 28 & & & \\
\hline
\end{tabular}

$1)=7$, and df $2(n-k-1)$ or $29-6-1=22$ ( $n$ is the number of samples and $k$ is the number of independent variables), the results obtained for $\mathrm{F}$ Table are 2,549

Test criteria

- H0 is accepted if $\mathrm{F}$ count $<\mathrm{F}$ table

- $\mathrm{H} 1$ is rejected if $\mathrm{F}$ count $>\mathrm{F}$ table

Compare $\mathrm{F}$ count with $\mathrm{F}$ table

$\mathrm{F}$ count $>\mathrm{F}$ table $(3,142>2,549)$, then $\mathrm{H} 0$ is rejected

\section{Partial Regression Coefficient Test (t Test)}

Table 7. Test Results $\mathrm{t}$

\begin{tabular}{llllllll}
\hline Model & \multicolumn{2}{l}{$\begin{array}{l}\text { Unstandardized } \\
\text { Coefficients } \\
\end{array}$} & \multicolumn{2}{l}{$\begin{array}{l}\text { Standardized } \\
\text { Coefficients } \\
\text { B }\end{array}$} & Std. Error & Beta & Sig. \\
\hline 1 & (Constant) & 1,409 &, 855 & & & \\
& X1 &, 093 &, 039 &, 402 & 2,648 &, 113 \\
& X2 &, 123 &, 062 &, 343 & 1,993 &, 027 \\
& X3 &, 008 &, 046 &, 031 &, 178 &, 861 \\
& X4 &, 044 &, 049 &, 148 &, 905 &, 375 \\
X5 &, 032 &, 047 &, 115 &, 691 &, 497 \\
& X6 &, 038 &, 044 &, 149 &, 848 &, 405 \\
\hline
\end{tabular}

\section{Testing Criteria}

$\mathrm{HO}$ is rejected if $\mathrm{t}$ count $<\mathrm{t}$ table

$\mathrm{H} 1$ is accepted if $\mathrm{t}$ count $>\mathrm{t}$ table

2. Comparing $t$ count with $t$ table

The value of $t$ count $>t$ table $(2,363>2,073)$ then $H 1$ is accepted 
Table 8. Independent Variable Partial Analysis of Dependents

\begin{tabular}{|c|c|c|c|c|}
\hline Variabel & No. Statement & $\mathrm{T}$ counts & $\mathrm{T}$ table & Analysis \\
\hline Participants & 1 & 2.363 & 2.073 & $\begin{array}{l}-\mathrm{T} \text { value count }<-\mathrm{t} \text { table } \\
(2,363<2,073) \text { then } \mathrm{H}_{0} \text { is accepted }\end{array}$ \\
\hline Trainer & 2 & 1.998 & 2.073 & $\begin{array}{l}-\mathrm{T} \text { value count }<-\mathrm{t} \text { table } \\
(1,998<2,073) \text { then } \mathrm{H}_{0} \text { is accepted }\end{array}$ \\
\hline Material & 3 & .178 & 2.073 & $\begin{array}{l}-\mathrm{T} \text { value count }<-\mathrm{t} \text { table } \\
(0,178<2,073) \text { then } \mathrm{H}_{0} \text { is accepted }\end{array}$ \\
\hline Environment & 4 & .905 & 2.073 & $\begin{array}{l}-\mathrm{T} \text { value count }<-\mathrm{t} \text { table } \\
(0,905<2,073) \text { then } \mathrm{H}_{0} \text { is accepted }\end{array}$ \\
\hline Location & 5 & .691 & 2.073 & $\begin{array}{l}-\mathrm{T} \text { value count }<-\mathrm{t} \text { table } \\
(0,691<2,073) \text { then } \mathrm{H}_{0} \text { is accepted }\end{array}$ \\
\hline Time & 6 & .149 & 2.073 & $\begin{array}{l}-\mathrm{T} \text { value count }<-\mathrm{t} \text { table } \\
(0,149<2,073) \text { then } \mathrm{H}_{0} \text { is accepted }\end{array}$ \\
\hline
\end{tabular}

\section{Conclusion}

From the results of the research that has been done, it can be concluded that, the influential indicator is the Instructor. The results of the $t$ test are obtained with the value of tcount> table $(2.363>2.073)$ then $\mathrm{Ha}$ is accepted, meaning that partially there is a significant influence between the variable Training (Independent) and the work performance of employees (dependent). Based on the results of the R square, the contribution of influence is only $70 \%$ and the results of the $\mathrm{f}$ test with Fcount> Ftable (3.142> 2.549), meaning that $\mathrm{HO}$ is rejected, meaning that there is a significant influence between the independent and dependent variables.

\section{References}

[1] H. Hamdan, "The Effect of Entrepreneurship Leadership and Motivation on Employees' Satisfaction at Serang Raya University," J. Terap. Manaj. Dan Bisnis, vol. 4, no. 2, p. 171, 2018.

[2] M. Coetzee and E. Stoltz, "Employees' satisfaction with retention factors: Exploring the role of career adaptability," J. Vocat. Behav., vol. 89, pp. 83-91, 2015.

[3] N. Lin, J. Jang, and K. R. Roberts, "Are employees with higher organization-based self-esteem less likely to quit? A moderated mediation model," Int. J. Hosp. Manag., vol. 73, no. July 2017, pp. 116-124, 2018.

[4] M. W. Staniewski and K. Awruk, "Entrepreneurial success and achievement motivation - A preliminary report on a validation study of the questionnaire of entrepreneurial success,” J. Bus. Res., vol. 101, no. January, pp. 433-440, 2019.

[5] J. A. Busser, L. V. Shulga, H. J. (Annette) Kang, and D. H. Ramirez Molintas, "The effect of hospitality conference messaging on employee job responses," Int. J. Hosp. Manag., vol. 78, no. May, pp. 284-292, 2019.

[6] N. Glaveli, E. Grigoroudis, and P. Manolitzas, "Practical application of MSQ and MUSA methodology in determining critical job satisfaction factors of seasonal employees in summer destination luxury resorts," Tour. Manag., vol. 74, no. May, pp. 
426-437, 2019.

[7] T. Vipraprastha, I. N. Sudja, and A. Yuesti, "The Effect of Transformational Leadership and Organizational Commitment to Employee Performance with Citizenship Organization (OCB) Behavior as Intervening Variables (At PT Sarana Arga Gemeh Amerta in Denpasar City)," Int. J. Contemp. Res. Rev., vol. 9, no. 2, pp. 20503-20518, 2018.

[8] I. Idris and H. Napitupulu, "PERANCANGAN SISTEM INFORMASI KAMPUS TERINTEGRASI DI LINGKUNGAN POLITEKNIK LP3I MEDAN,” J. Teknovasi, vol. 2, no. 1, pp. 22-32, 2015.

[9] I. I. Doni Efriza, "Produktivitas kerja karyawan perbankan di kota medan," J. BIS-A, vol. 5, no. 2, pp. 49-53, 2018.

[10] F. Maillard, B. Pereira, and N. Boisseau, "Effect of High-Intensity Interval Training on Total, Abdominal and Visceral Fat Mass: A Meta-Analysis," Sport. Med., vol. 48, no. 2, pp. 269-288, 2018 .

[11] . N., A. Yolanda, and A. S. R. Br.Purba, "Effect of Work Conflict on the Employee Motivation," KnE Soc. Sci., vol. 3, no. 4, p. 642, 2018.

[12] J. Browne, A. N. Edwards, D. L. Penn, P. S. Meyer-Kalos, J. D. Gottlieb, P. Julian, K. Ludwig, K. T. Mueser, and J. M. Kane, "Factor structure of therapist fidelity to individual resiliency training in the Recovery After an Initial Schizophrenia Episode Early Treatment Program," Early Interv. Psychiatry, vol. 12, no. 6, pp. 1052-1063, 2018.

[13] A. Azevedo and M. J. Shane, "A new training program in developing cultural intelligence can also improve innovative work behavior and resilience: A longitudinal pilot study of graduate students and professional employees," Int. J. Manag. Educ., vol. 17, no. 3, p. 100303, 2019.

[14] L. Xiong and C. King, "Aligning employees' attitudes and behavior with hospitality brands: The role of employee brand internalization," J. Hosp. Tour. Manag., vol. 40, no. November 2018, pp. 67-76, 2019.

[15] A. Lin, G. Nadarajah, M. Sharif, A. Bhuiyan, and M. Islam, "The factors that affect the effectiveness of training: a study at Silterra Malaysia Sdn. Bhd., a semiconductor company in Malaysia," Int. J. Manag. Stud., vol. 22, no. S, pp. 33-46, 2015.

[16] A. A. Anwar Prabu Mangkunegara, Manajemen Sumber Daya Manusia Perusahaan, no. 13. Bandung: PT. Remaja Rosda Karya Offset, 2015.

[17] E. Sutrisno, MANAJEMEN SUMBER DAYA MANUSIA. Prenada Media Group, 2014.

[18] M. S. P. Hasibuan, Manajemen Sumber Daya Manusia (Edisi Revisi), no. 18. BUMI AKSARA, 2014.

[19] H. Harmen, F. Agustini, L. M. Harahap, and D. Amanah, "Analysis of Factors Influencing the Visitor Satisfaction on Pantai Cermin, Indonesia," IOSR J. Bus. Manag., vol. 19, no. 6, pp. 47-53, 2017.

[20] Tipalti, "What is the Difference Between Limit Test and Assay - Pediaa.Com," Quora, 2014. [Online]. Available: https://www.quora.com/What-is-the-difference-betweenchi-square-test-and-F-test. [Accessed: 20-Jun-2019].

[21] Surbhi S, "Difference Between Questionnaire and Interview (with Comparison Chart) - Key Differences," Keydifferences, 2016. [Online]. Available: https://keydifferences.com/difference-between-questionnaire-and-interview.html. [Accessed: 20-Jun-2019].

[22] Kasmir, Manajemen Sumber Daya Manusia (TEORI DAN PRAKTIK), 5th ed. Jakarta: PT. Raja Grafindo Persada, 2019. 
